\title{
Prediksi Aktivitas Biologis Metabolite Sekunder Amphora Sp. secara insilico: Untuk Pengembangan Bahan Obat Alami
}

\section{Insilico Prediction of Biological Activity of Secondary Metabolites of Amphora sp.: for Development of Natural Medicines}

\author{
Ach. Khumaidi ${ }^{1 *}$, Abdul Wafi, Abdul Muqsith ${ }^{1}$ \\ ${ }^{1}$ Program Studi Budidaya Perikanan, Fakultas Sains dan Teknologi, Universitas Ibrahimy \\ Jl. Raya Situbondo-Banyuwangi, Sumberejo, Situbondo, Jawa Timur 68374, Indonesia. \\ *alamat email: ach.khumaidi@gmail.com
}

\begin{abstract}
Abstrak
Diatom Amphora sp. merupakan jenis produk budidaya perikanan yang memiliki berbagai macam jenis metabolite dengan potensi sangat baik untuk dijadikan sebagai bahan dasar obat atau produk kesehatan lainnya. Analisis insilico ekstrak Amphora sp. dilakukan untuk memprediksi aktivitas biologis yang dapat dijadikan pijakan pengembangan pemanfaatan produk budidaya perikanan. Penelitian dilakukan dengan melakukan ekstraksi Amphora sp. menggunakan pelarut etanol dengan metode sonikasi, hasil ekstraksi dianalisis dengan LC-HRMS, dan hasil pembacaan metabolit kemudian dianalisis potensi obat dan aktivitas bilogis secara online dengan aplikasi swissADME, Protox II, dan Way2Drug. Hasil analisis LC-HRMS menunjukkan Amphora sp. yang diekstrak menunjukkan adanya senyawa valine memiliki kelimpahan tertinggi dengan $17.6 \%$ serta senyawa lainnya L-Norleucin, stearamide, palmitoleic acid, isotretinoin, dan arachidonic acid. Hasil analisis ADME/T menunjukkan bahwa 6 senyawa ekstrak Amphora sp. memiliki potensi cukup baik sesuai dengan aturan Lipinski rule of five. Aktivitas biologis juga menunjukkan potensi sebagai agen antiinflamasi, antifungi, antibakteri, antivirus, dan antineoplastik dengan nilai Pa. berkisar antara 0.260 - 0.873. Hasil ini menunjukkan bahwa pengembangan produksi budidaya Amphora sp. dan pemanfaatannya sangat luas termasuk pada bidang kesehatan.
\end{abstract}

Kata Kunci: ADME/T, PASSonline, Amphora sp., sonikasi, akuakultur.

\begin{abstract}
Diatom Amphora sp. is a type of aquaculture product that has various types of metabolites with very good potential to be used as basic ingredients for drugs or other health products. Insilico analysis of extracts of Amphora sp. was carried out to predict biological activity that can be used as a basis for developing the use of aquaculture products. The research was conducted by extracting Amphora sp. using ethanol solvent with sonication method, the extraction results were analyzed by LC-HRMS, and the metabolite readings were then analyzed for drug potential and biological activity online using swissADME, Protox II, and Way2Drug applications. The results of the LC-HRMS analysis showed that the extracted Amphora sp. showed the highest abundance of valine compounds with $17.6 \%$ as well as other compounds L-Norleucin, stearamide, palmitoleic acid, isotretinoin, and arachidonic acid. The results of the ADME/T analysis showed that the six compounds of Amphora sp. extract had quite good potential according to the Lipinski rule of five. Biological activity also shows potential as an antiinflammatory, antifungal, antibacterial, antiviral, and antineoplastic agent with Pa values ranging from 0.260 to 0.873 . These results indicate that the production development of Amphora sp. and its use is very wide, including in the health sector.
\end{abstract}

Keyword: ADME/T, PASSonline, Amphora sp., sonication, aquaculture. 


\section{PENDAHULUAN}

Perkembangan dunia industri mikroalga secara global semakin meningkat. Pada beberapa tahun terakhir, mikroalga diproduksi tidak hanya untuk kepentingan sebagai pakan alami pada budidaya ikan atau udang. Metabolite sekunder dalam bentuk senyawa bioaktif yang terkandung di beberapa jenis mikroalga seperti polifenol, karotenoid dan berbagai macam senyawa aktif lainnya diekplorasi sebagai bahan antioksidan, antiviral, dan aktivitas biologis lainnya di bidang kesehatan (Haoujar et al., 2019). Produksi metabolit sekunder berbeda dengan produksi makromolekul universal dari metabolisme primer seperti monosakarida, polisakarida, asam amino, protein, dan termasuk lipid yang umumnya diproduksi oleh semua organisme (Silva, Rocha-santos, \& Duarte, 2016). Metabolit sekunder memiliki pola distribusi yang ketersediaan terbatas di alam karena tidak selalu diproduksi pada semua kondisi kultur dan hanya dapat ditemukan pada organisme tertentu atau sekelompok organisme.

Amphora sp., termasuk salah satu jenis mikroalga golongan Bacilariophyceae yang memiliki potensi cukup baik untuk pengembangan produksi senyawa bioaktif penting untuk kesehatan. Menurut Boukhris et al. (2017) Amphora sp. memiliki kandungan protein, lipid, gula, dan mineral dalam persentase sedang, serta metabolit penting seperti polifenol, flavonoid, klorofil, karotenoid, dan asam lemak bioaktif sebagai EPA, serta terbukti memiliki aktifitas biologis penting sebagai antioksidan dan antibakteri. Pada penelitian sebelumnya, diungkapkan bahwa Amphora sp. yang diisolasi dari perairan Situbondo (Indoensia) memiliki kandungan nutrisi yang cukup baik (Khumaidi et al. 2020), asam lemak penting (Khumaidi et al. 2020), meningkatkan kelulushidupan ikan Kerapu Cantang yang terinfeksi virus (Khumaidi and Umiyah 2019).

Pengembangan potensi metabolit sekunder dapat dipelajari berdasarkan kemiripan strukturalnya dengan senyawa aktif yang diketahui. Potensi penggunaan metabolit sekunder sebagai agen terapeutik sebagian besar bergantung pada farmakokinetik dan farmakodinamiknya. $\quad$ Fase farmakokinetik meliputi absorpsi, distribusi, metabolisme, dan eliminasi 
Journal of Aquaculture Science

DOI: https://doi.org/10.31093/joas.v6i1IS.163
July 2021 Vol 6 Issue Spesial: 110-118

Online pada http://joas.co.id

Tepung atau bubuk Amphora sp. berasal dari kultur secara mandiri. Pupuk yang digunakan saat kultur Amphora sp. yaitu $\mathrm{KNO}_{3}, \mathrm{NaH}_{2} \mathrm{PO}_{4}, \mathrm{Na}_{2}$ EDTA, $\mathrm{FeCl}_{3}$, Silikate, larutan mikro ( $\mathrm{Zn} \mathrm{Cl}_{2} ; \mathrm{CoCl}_{2}$; $6 \mathrm{H}_{2} \mathrm{O} ; \quad$ (NH4)6,MO7,O24,4H2O; $\mathrm{CuSO}_{4}$; $5 \mathrm{H}_{2} \mathrm{O}$ ), dan vitamin (B1 dan B12). Kualitas air pada saat kultur dikondisikan optimal sesuai pertumbuhan Amphora sp. Panen Amphora sp. dilakukan pada hari ke-5 kultur dengan kepadatan $230 \times 10^{4} \mathrm{sel} / \mathrm{cm}$. Hasil pemanenan Amphora sp. dikeringkan pada kondisi suhu ruangan selama 3 hari, kemudian diblender untuk mendapatkan Amphora sp. dalam bentuk tepung atau bubuk.

\section{- Ekstraksi}

Amphora sp. diekstraksi dengan metode sonikasi menggunakan pelarut etanol pa. dengan perbandingan $1: 10$ yaitu bubuk Amphora sp. (30 gr) : pelarut (300 $\mathrm{ml}$ ). Sonikasi dilakukan dengan $20 \mathrm{Khz}$ selama 15 menit. Hasil sonikasi dilakukan penyaringan menggunakan kertas saring (Whatman no. 42) untuk memisahkan ampas dengan ekstrak hasil pelarutan.

Filtrat yang dihasilkan, kemudian dipekatkan dengan cara dievaporasi dengan rotary evaporator vacum pada suhu $40{ }^{\circ} \mathrm{C}$, kecepatan $60 \mathrm{rpm}$, dan tekanan $200 \mathrm{mBar}$. Selanjutnya dilakukan penghitungan rendemen dengan menggunakan :

$$
\% \text { rendemen }=
$$

$\frac{\text { berat ekstrak kasar yang diperoleh }}{\text { berat sampel yang digunakan }} \times 100 \%$
Rancangan penelitian

- Bubuk Amphora sp. 


\section{LC-HRMS}

Profiling bioaktif ekstrak Amphora sp. dilakukan dengan LCHRMS mengikuti Najafian dan Babji (2014) dengan modifikasi. Ekstrak Amphora sp. dilarutkan dengan pelarut etanol dengan volume final $1300 \mu \mathrm{l}$. LC-HRMS yang digunakan model Thermo Scientific Dionex Ultimate 3000RSLCnano dengan microflow meter dengan dilengkapi auto sampler, binary pump, column compartment dan Diode Array Detector untuk scanning spektroskopik. Data MS diperoleh dengan pemindaian secara penuh pada resolusi 70.000. Sedangkan data kromatogram yang diperoleh didasarkan dari sistem atau library mz Cloud yang digunakan.

\section{Analisis data (Insilico)}

Analisis potensi agen terapeutik dari ekstrak Amphora sp. mengacu pada Amin et al., (2018). Beberapa senyawa bioaktif hasil dari analisis LC-HR/MS diolah dan dianalisis secara insilico. Informasi fitokimia bioaktif Amphora sp. diperoleh dengan cara mengakses server

PubChem

(https://pubchem.ncbi.nlm.nih.gov/)

seperti sinonim, canonical SMILES dan Isomeric SMILES, serta struktur 3D senyawa bioaktif. Prediksi farmakokinetika ADME (http://www.swissadme.ch/) dan toksisitas

http://tox.charite.de/protox_II/, prediksi bioaktivitas dengan PASS online (http://www.way2drug.com/PASSOnlin e/index.php).

\section{HASIL DAN PEMBAHASAN}

Hasil analisis data kromatogram LC-HRMS terdapat enam puluh dua (62) kromatogram (Gambar 1). Dari hasil tesebut dilakukan filterisasi berdasarkan angka mzCloud BestMact $\geq 80$ serta senyawa yang memiliki relative kelimpahan yang besar. Hasil filterisasi menunjukan ada enam senyawa aktif yang diduga kuat merupakan senyawa aktif dari ekstrak Amphora sp (Tabel 1). Prediksi stuktur senyawa kimia diakses melalui laman (https://pubchem.ncbi.nlm.nih.gov/). 
Journal of Aquaculture Science

DOI: https://doi.org/10.31093/joas.v6i1IS.163

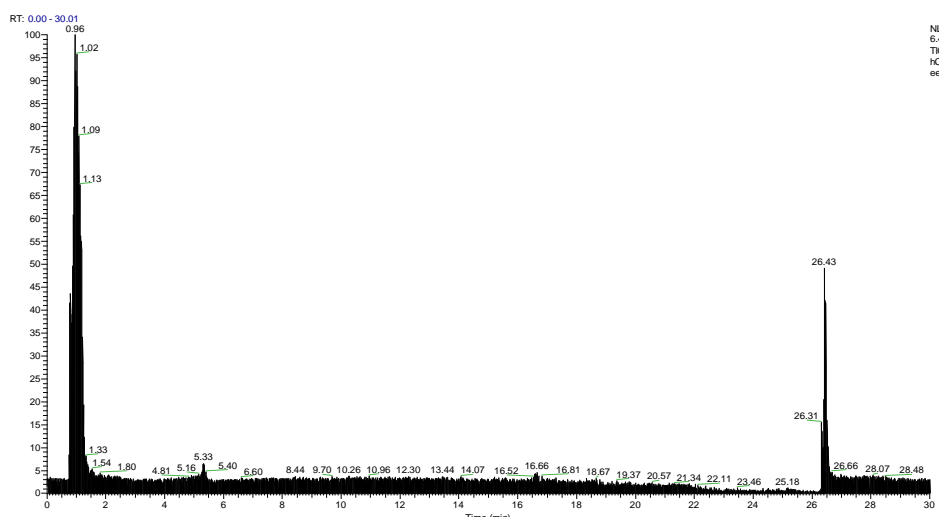

Gambar 1. Spektrum LC-HRMS ekstrak Amphora sp.

Tabel 1. Hasil LC-HRMS ekstrak Amphora sp.

\begin{tabular}{lccccc}
\hline \multicolumn{1}{c}{ Name } & Formula & RT [min] & Area (Max.) & $\begin{array}{c}\text { mzCloud } \\
\text { Best Match }\end{array}$ & $\begin{array}{c}\text { Kelimpahan } \\
(\boldsymbol{\%})\end{array}$ \\
\hline Valine & C5 H11 N O2 & 0.931 & $21,148,092.11$ & 82.6 & 17.6 \\
L-Norleucine & C6 H13 N O2 & 0.93 & $10,583,783.92$ & 84.3 & 8.8 \\
Stearamide & C18 H37 N O & 20.523 & $8,220,643.35$ & 86.5 & 6.9 \\
Palmitoleic acid & C16 H30 O2 & 16.624 & $4,411,520.04$ & 90 & 3.7 \\
Isotretinoin & C20 H28 O2 & 11.86 & $2,306,530.66$ & 83.7 & 1.9 \\
$\begin{array}{l}\text { Arachidonic } \\
\text { acid }\end{array}$ & C20 H32 O2 & 16.619 & $1,833,046.56$ & 95.2 & 1.6 \\
\hline
\end{tabular}

Hasil analisis menunjukkan bahwa senyawa Valine memiliki kelimpahan tertinggi dengan $17.6 \%$ pada waktu retensi 0.931 , dan diikuti senyawa lainnya seperti pada (Tabel 1) dan terakhir Arachinoic acid 1.6\% pada waktu retensi 16.624. Enam senyawa tersebut memiliki rentang mzCloud BestMatch $>80$.

Valine (L-valine), asam amino- $\alpha$ yang memiliki fungsi penting dalam sintesis bioprotein. Secara spesifik, asam amino ini tidak dapat dibentuk atau diproduksi oleh tubuh manusia dan hewan, yang berarti asam amino ini harus ditambahkan dari luar tubuh melalui makanan. Asam amino esensial ini berperan dalam kelancaran sistem saraf dan fungsi kognitif, perbaikan jaringan yang rusak serta peningkatan sistem kekebalan tubuh. Selain itu, Lvaline banyak digunakan untuk bahan pembuatan antivirus seperti valacyclovir (Valtrex) (Ormrod, Scott, \& Perry, 2000) dan valganciclovir (Valcyte) (Curran \& Noble, 2001) yang dapat melawan herpes simplex virus tipe I dan tipe II, varicella zoster virus dan human cytomegalovirus (HCMV).

Selain Valine, senyawa lain seperti L-Norleucine banyak digunakan untuk mengatasi penyakit Alzheimer (Clementi \& Misiti, 2005). Searamide memiliki aktivitas antibakteri 
Staphylococcus epidermidis (Ahmed et al., 2017). Palmitoleic acid, atau (9Z)hexadec-9-enoic acid dapat berfungsi untuk menurunkan resiko diabetes dan menurunkan resiko kardiovaskular (Mozaffarian et al., 2010; Stefan et al., 2010). Isotretinoin termasuk turunan dari vitamin A yang telah banyak digunakan dalam pengobatan jerawat dengan peran mempengaruhi perkembangan siklus sel, diferensiasi sel, kelangsungan hidup sel dan apoptosis. Isotretinoin juga dinilai efektif untuk pengobatan ficulitis eosinofilik yang berhubungan dengan human immunodeficiency virus (Layton, 2009).

Arachidonic acid (ARA) merupakan asam lemak omega-6 tak jenuh ganda 20:4 ( $\omega-6)$, atau 20:4 $(5,8,11,14)$ yang memiliki peran mendasar pada fungsi otak dan otot terutama pada kasus infeksi Schistosoma mansoni dan $S$. Haematobium. ARA juga memiliki fungsi mampu meningkatkan dan memodulasi respons imun tipe 2, yang mengatur resistensi terhadap parasit dan serangan alergen (Tallima \& El Ridi, 2018).

Tabel 2. Analisis ADME senyawa aktif ekstrak Amphora sp.

\begin{tabular}{|c|c|c|c|c|c|c|c|c|}
\hline Name & $\begin{array}{l}\text { Canonical } \\
\text { SMILES }\end{array}$ & MW & HBA & HBD & $\begin{array}{l}\text { TPSA } \\
\left(\mathbf{A}^{\mathbf{O}}\right)\end{array}$ & $\begin{array}{c}\log P \\
(\text { iLOGP) }\end{array}$ & $\begin{array}{c}\mathbf{L D}_{50} \\
(\mathrm{mg} / \mathrm{kg} \\
)\end{array}$ & $\begin{array}{l}\text { Toxicit } \\
\text { y Class }\end{array}$ \\
\hline Valine & $\begin{array}{c}\mathrm{CC}(\mathrm{C}) \mathrm{C}(\mathrm{C}(= \\
\mathrm{O}) \mathrm{O}) \mathrm{N}\end{array}$ & $\begin{array}{c}117.07 \\
898\end{array}$ & 3 & 2 & 63.3 & 1.03 & 12680 & 6 \\
\hline L-Norleucine & $\begin{array}{c}\operatorname{CCCCC}(\mathrm{C}(= \\
\text { O)O }) \mathrm{N}\end{array}$ & $\begin{array}{c}131.09 \\
45\end{array}$ & 3 & 2 & 63.2 & 1.17 & 260 & 3 \\
\hline Stearamide & $\begin{array}{c}\mathrm{CCCCCCC} \\
\mathrm{CCCCCCC} \\
\mathrm{CCCC}(=\mathrm{O}) \\
\mathrm{N}\end{array}$ & $\begin{array}{c}283.28 \\
67\end{array}$ & 1 & 1 & 43.09 & 4.22 & 958 & 4 \\
\hline Palmitoleic acid & $\begin{array}{c}\mathrm{CCCCCCC}= \\
\mathrm{CCCCCCC} \\
\mathrm{CC}(=\mathrm{O}) \mathrm{O}\end{array}$ & $\begin{array}{c}254.22 \\
409\end{array}$ & 2 & 1 & 37.3 & 3.53 & 48 & 2 \\
\hline Isotretinoin & $\begin{array}{c}\mathrm{CC} 1=\mathrm{C}(\mathrm{C}(\mathrm{C} \\
\mathrm{CC} 1)(\mathrm{C}) \mathrm{C}) \mathrm{C} \\
=\mathrm{CC}(=\mathrm{CC}= \\
\mathrm{CC}(=\mathrm{CC}(=\mathrm{O} \\
) \mathrm{O}) \mathrm{C}) \mathrm{C}\end{array}$ & $\begin{array}{c}300.20 \\
833\end{array}$ & 2 & 1 & 37.3 & 3.68 & 1100 & 4 \\
\hline $\begin{array}{l}\text { Arachidonic } \\
\text { acid }\end{array}$ & $\begin{array}{c}\mathrm{CCCCCC}=\mathrm{C} \\
\mathrm{CC}=\mathrm{CCC}=\mathrm{C} \\
\mathrm{CC}=\mathrm{CCCCC} \\
(=\mathrm{O}) \mathrm{O}\end{array}$ & $\begin{array}{c}304.23 \\
961\end{array}$ & 2 & 1 & 37.3 & 4.64 & 10000 & 6 \\
\hline
\end{tabular}


Journal of Aquaculture Science

DOI: https://doi.org/10.31093/joas.v6i1IS.163
July 2021 Vol 6 Issue Spesial: 110-118

Online pada http://ioas.co.id
Senyawa aktif Amphora sp. memiliki berat molekul antara 117 $304 \mathrm{~g} / \mathrm{mol}$ memperlihatkan nilai biovabilitas, penyerapan fraksi, dan pembersihan pada ginjal yang baik. Lipinski et al., (2012) mengungkapkan bahwa nilai MW yang melebihi 500 $\mathrm{g} / \mathrm{mol}$ memiliki aktivitas bioavabilitas, penyerapan fraksi, dan pembersihan pada ginjal yang rendah.

Nilai TPSA pada semua senyawa aktif juga memiliki nilai $\leq 140$, yang mengindikasikan senyawa aktif dapat mudah masuk ke dalam sel (Aristyani et al., 2018). Nilai toksisitas $\left(\mathrm{LD}_{50}\right)$ ekstrak Amphora sp.

menunjukkan nilai toksisitas berkisar 48 - $12680 \mathrm{mg} / \mathrm{kg}$ dan dikategorikan dalam kelas 2 - 6. Senyawa Palmitoleic acid menunjukkan nilai toksisitas tertinggi yaitu $48 \mathrm{mg} / \mathrm{kg}$ dan berada pada kelas 2 toksisitas. Supandi et al., (2018) mengungkapkan semakin tinggi nilai $\mathrm{LD}_{50}$, maka nilai toksisitasnya semakin rendah terhadap hewan coba.

Hasil prediksi aktivitas biologis menunjukkan senyawa aktif ekstrak Amphora sp. memiliki aktivitas sebagai agen antiinflamasi, antifungi, antibakteri, antivirus, dan antineoplastik dengan nilai Pa. berkisar antara $0.260-$ 0.873 (Gambar 2). Dari enam senyawa ekstrak Amphora sp., valine dan stearamide menunjukkan belum memiliki aktivitas antioksidan secara langsung.

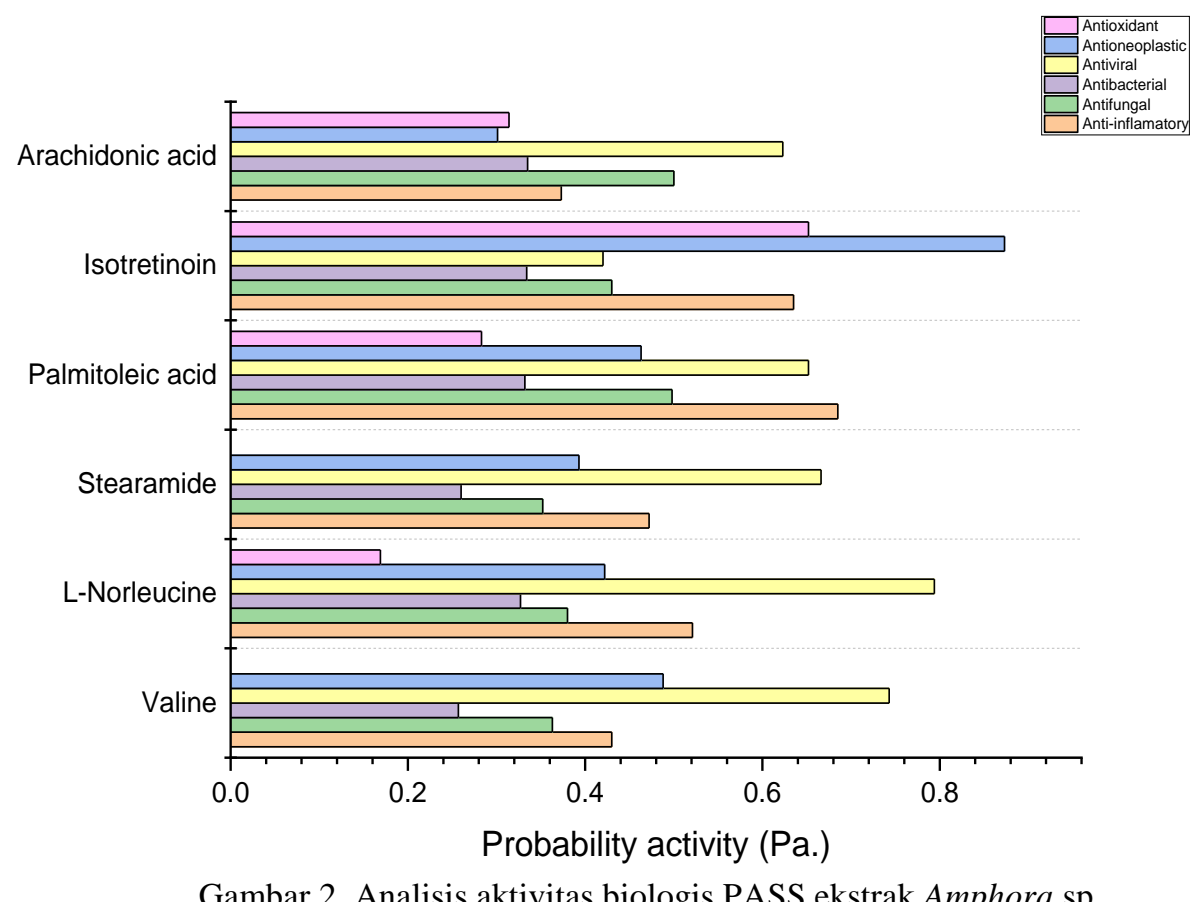

Gambar 2. Analisis aktivitas biologis PASS ekstrak Amphora sp. 
Tabel 3. Prediksi aktivitas antivirus ekstrak Amphora sp.

\begin{tabular}{lccccccc}
\hline \multirow{2}{*}{ Name } & \multicolumn{7}{c}{ Antiviral } \\
\cline { 2 - 9 } & $\begin{array}{c}\text { Picorna } \\
\text { virus }\end{array}$ & $\begin{array}{c}\text { Influen } \\
\text { za }\end{array}$ & $\begin{array}{c}\text { Poxvir } \\
\text { us }\end{array}$ & $\begin{array}{c}\text { Adhenov } \\
\text { irus }\end{array}$ & Rhinovirus & $\begin{array}{c}\text { Cytomega } \\
\text { lovirus }\end{array}$ & $\begin{array}{c}\text { Herpesvi } \\
\text { rus }\end{array}$ \\
\hline \hline Valine & 0.743 & 0.511 & 0.469 & 0.512 & 0.419 & 0.441 & 0.421 \\
L-Norleucine & 0.794 & 0.66 & 0.602 & 0.523 & 0.479 & 0.408 & 0.378 \\
Stearamide & 0.666 & 0.575 & 0.586 & 0.473 & 0.431 & 0.37 & 0.371 \\
Palmitoleic acid & 0.628 & 0.652 & 0.482 & 0.483 & 0.637 & 0.558 & 0.433 \\
Isotretinoin & 0.391 & 0.262 & - & 0.263 & 0.403 & 0.214 & 0.42 \\
Arachidonic acid & 0.597 & 0.599 & 0.429 & 0.461 & 0.623 & 0.533 & 0.421 \\
\hline
\end{tabular}

Secara spesifik juga dilakukan analisis pada aktivitas antivirus (Gambar 3). Hasil analisis menunjukkan bahwa senyawa aktif ekstrak Amphora sp. memiliki aktivitas antivirus pada Cytomegalovirus, Rhinovirus, Adhenovirus, Poxvirus, Influenza, dan Picornavirus. Prediksi aktivitas kuat sebagai antivirus dengan nilai $\geq 0.7$ terlihat pada Valine dan L-Norleucine yang memiliki aktivitas anti Picornavirus dengan nilai Pa. (0.743 dan 0.794). Nilai prediksi PASS $\geq 0.7$ (kotak biru) pada Tabel 3 menunjukkan aktivitas yang sangat memungkinkan terjadi dalam percobaan secara invivo, dan memiliki kemungkinan kesamaan dengan obat lain yang sudah dikenal (Lagunin et al., 2000). Melihat hasil prediksi aktivitas biologis secara insilico, menunjukkan bahwa metabolit sekunder dari Ekstrak Amphora sp. memiliki potensi yang cukup baik untuk dikembangkan sebagai bahan dasar obat atau agen terapeutik di bidang kesehatan.

\section{KESIMPULAN}

Amphora sp. yang diekstrak dengan pelarut etanol dengan metode sonikasi menunjukkan adanya beberapa metabolit sekunder yaitu valine, LNorleucine, stearamide, palmitoleic acid, isotretinoin, dan arachidonic acid. Metabilit sekunder Amphora sp. secara insilico menunjukkan potensi agen terapeutik sebagai antineoplastik, antibakteri, antifungi, antioksidan, dan antivirus.

\section{DAFTAR PUSTAKA}

Ahmed, S., Liu, H., Ahmad, A., Akram, W., Abdelrahman, E. K. N., Ran, F., ... Hu, X. Frontiers in Microbiology (2017). 8(OCT): 1-11.

Amin, M., Putra, K. S., Amin, I. F., Earlia, N., Maulina, D., Lukiati, B., \& Lestari, U. Biology, Medicine, \& Natural Product Chemistry, (2018) 7(1): 27-31.

Aristyani, S., Nur, M. I., Widyarti, S., Sumitro, S. B., Sciences, N., \& Sciences, N. 2018. In silico study of active compounds ADMET Profiling in Curcuma xanthorrhiza Roxb and Tamarindus indica 
Journal of Aquaculture Science

DOI: https://doi.org/10.31093/joas.v6i1IS.163
July 2021 Vol 6 Issue Spesial: 110-118

Online pada http://joas.co.id as Tuberculosis Treatment. Jurnal Jamu Indonesia, 3(3): 101-108.

Boukhris, S., Athmouni, K., Hamza-Mnif, I., Siala-Elleuch, R., Ayadi, H., Nasri, M., \& Sellami-Kamoun, 2017. A. BioMed Research International.

Clementi, M. E., \& Misiti, F. 2005. Substitution of methionine 35 inhibits apoptotic effects of $A \beta(31-35)$ and $A \beta(25-35)$ fragments of amyloid-beta protein in PC12 cells. Medical Science Monitor, 11(11): 381385.

Curran, M., \& Noble, S. 2001. Valganciclovir. Drugs, 61(8): 1145-1150.

Haoujar, I., Cacciola, F., Abrini, J., Mangraviti, D., Giuffrida, D., El Majdoub, Y. O., ... Senhaji, N. S. Molecules (2019). 24(22): $1-17$.

Khumaidi, A, Iranawati, F., Kilawati, Y., Yanuhar, U., \& Fadjar, M. 2020. Morphology, molecular, and nutritional value of Amphora sp . from coastal water of the grouper cultivation center (Situbondo, Indonesia). Ecology, Environment and Conservation, 26(2): 943-949.

Khumaidi, A, \& Umiyah, A. 2019. Potensi Antivirus Viral Nervous Necrosis Ekstrak Metanol Amphora sp . pada Ikan Kerapu Cantang ( Epinephelus sp .). Samakia: Jurnal Ilmu Perikanan, 10(2): 114-120.

Khumaidi, Ach, Iranawati, F., Fadjar, M., Maftuch, Masruri, Yanuhar, U., \& Kilawati, Y. 2020. Fatty acid profile and in silico pharmacological study of diatom amphora sp. AACL Bioflux, 13(4): 20502060.
Lagunin, A., Stepanchikova, A., Filimonov, D., \& Poroikov, V. Bioinformatics Applications Note (2000). 16(8): 747-748. https://doi.org/10.1093/bioinformatics/16. 8.747

Layton, A. Dermato-Endocrinology (2009). 1(3): 162-169.

Lipinski, C. A., Lombardo, F., Dominy, B. W., \& Feeney, P. J. Advanced Drug Delivery Reviews (2012). 64(SUPPL.): 4-17.

Mozaffarian, D., Cao, H., King, I. B., Lemaitre, R. N., Song, X., Siscovick, D. S., \& Hotamisligil, G. S. American Journal of Clinical Nutrition (2010). 92(6): 13501358.

Ormrod, D., Scott, L. J., \& Perry, C. M. Drugs (2000). 59(4): 839-863.

Silva, R. P. F. F., Rocha-santos, T. A. P., \& Duarte, A. C. 2016. Supercritical fluid extraction of bioactive compounds. $\operatorname{Tr} A C$ Trends in Analytical Chemistry, 76: 4051.

Stefan, N., Kantartzis, K., Celebi, N., Staiger, H., Machann, J., Schick, F., ... Häring, H. U. Diabetes Care (2010). 33(2): 405-407.

Supandi, Yeni, \& Merdekawati, F. Journal of Applied Pharmaceutical Science (2018). 8(9): 119-129.

Tallima, H., \& El Ridi, R (2018). Journal of Advanced Research, 11: 33-41.

van de Waterbeemd, H., \& Gifford, E. Nature Reviews Drug Discovery (2003). 2(3): 192-204.

Wang, Y., Xing, J., Xu, Y., Zhou, N., Peng, J., Xiong, Z., \& Liu, X. Quarterly Reviews of Biophysics (2015). 48(4): 488-515. 